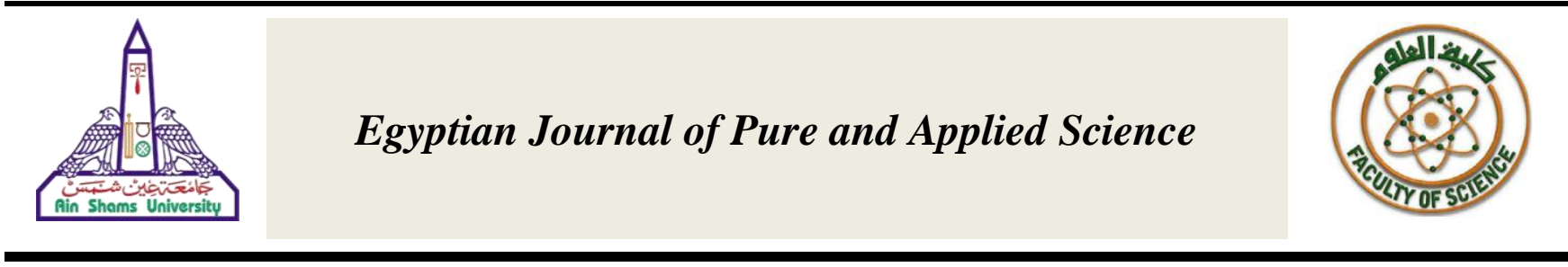

\title{
Hydrogeological Studies on the Shallow Aquifers in the Area West Samalot, El-Minia Governorate, Egypt
}

\author{
Ali Abdel Ati Ali Salem \\ Geology Department, Desert Research Center, Cairo, Egypt,
}

\section{A R T I C L E I N F O}

Article history:

Received 22 November 2015

Accepted 14 January 2016

Keywords:

Hydrogeology;

Shallow Aquifers;

Middle Eocene;

Groundwater;

West Samalot.

\begin{abstract}
A B S T R A C T
The present work aims to study the hydrogeological settings of the topmost aquifers along the area lying West of Samalot (El-Minia Governorate). To achieve this target, the field geomorphologic features, the geologic exposures and structures are investigated. The subsurface successions are detected through the collected data of the drilled wells from the rigs of the Arab Contracting drilling Company (ECDC) during the field investigations. In addition, the archival data as well drilling reports and well log charts from the office of this company. The groundwater level in these wells and along the nearest eastern irrigation water canal is recorded. Pumping and recovery tests are carried out on six wells. Thirty three groundwater samples are collected and are subjected to chemical analysis. The Middle Eocene (Samalot Formation) fractured limestone is the available water bearing rocks in the investigated area. The maximum penetrated thickness reaches $225 \mathrm{~m}$. It occurs under free water table conditions. The geometry of the aquifer is controlled by the fracture density, caving and fissuring. The depth to water ranges between $109.43 \mathrm{~m}$ to the West and $14.30 \mathrm{~m}$ to the East. The groundwater flows to the east and northeast towards Abo Edahab irrigation canal which acts as a discharging area rather than recharging one. An annual drop in water level occurs. It ranges between $0.5 \mathrm{~m}$ and $2.45 \mathrm{~m}$. The aquifer transmissivity ranges between $4394.9 \mathrm{~m}^{2} / \mathrm{d}$ and $3515.929 \mathrm{~m}^{2} / \mathrm{d}$ (high potentiality) along the eastern parts. However, it ranges between $274.68 \mathrm{~m}^{2} / \mathrm{d}$ and $15.13 \mathrm{~m}^{2} / \mathrm{d}$ (moderate potentiality) in the western parts. Most of the analyzed groundwater samples are of sodium chloride and some of sodium sulphate water types. Some recommendations are given in order to best use of the available groundwater wells and the future exploration for new occurrences.
\end{abstract}

\section{Introduction}

Horizontal and vertical expansion of the new communities and reclamation projects are the main strategic targets of the Egyptian Government. The exploration and evaluation of the water resources with special emphasis to the groundwater in the desert outskirts represent the backbone of these development projects.

The area of study occupies a portion of the Western desert fringes of Samalot (El-Minia Governorate) (Fig. 1). It includes the western old Nile alluvial terraces and the eastern part of the limestone plateau. It receives some of the internal migration of inhabitants locking for new lands for cultivation activities. The area of study extends between longitudes $30^{\circ} 20^{\circ}$ and $30^{\circ} 45^{\circ} \mathrm{E}$, and latitudes $28^{\circ} 10^{\circ}$ and $28^{\circ} 30^{\circ} \mathrm{N}$. El- Minia area is

\footnotetext{
* Corresponding author.

E-mail address: Dr_Ali.salem@yahoo.com
}

characterized by arid climate of warm winter and hot summer. The annual mean rainfall intensity reaches $19.6 \mathrm{~mm}$.

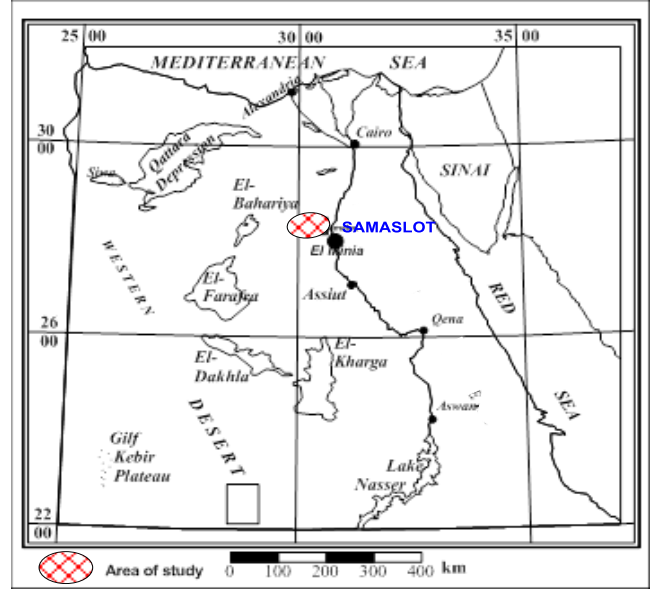

Fig. 1: The location of the area of study. 


\section{Geomorphologic setting}

The geomorphic units are given (Fig. 2) using the topographic maps (scale: 1:50000), the geologic maps and field investigations as follows:

\section{1- The limestone plateau}

The limestone plateau covers the western part of the investigated area. It is bounded by a structural scarp. Its surface slopes eastward with elevations range between $+175 \mathrm{~m}$ and $+90 \mathrm{~m}$ (Fig. 3). It is structurally controlled by step faults introducing the rift of the Nile basin. Around Darb ElRouby road, the plateau surface is interrupted by some structural isolated hills as Abu Rouh (+180 m), Basalt Hill (+102 m) and Abu Sedhom $(+132 \mathrm{~m})$. The western desert road (Cairo-Assuit) and the sand dune strain cross the eastern portion of the limestone plateau in N-S direction. The surface of the plateau is dissected by some drainage lines which run eastward. To the east of the sand dune strain, the limestone plateau disappears beneath the old river terraces and Recent Nile sediments.

\section{2- Old alluvial plain (River terraces)}

The old alluvial plain is a Transition zone between the cultivated lands (recent flood plain) and the high lands of the limestone plateau. The elevation of the old alluvial plain ranges between $10 \mathrm{~m}$ and $25 \mathrm{~m}$ above the recent flood plain. It is also covered by coarse sand and gravel which is considered as quarrying areas.

\section{3-Recent alluvial plain}

It occupies the area between the old alluvial plain eastward till the current Nile river channel. Its surface slopes northward with elevations range between $+25.5 \mathrm{~m}$ and $+26.5 \mathrm{~m}$. It is also striated by the main irrigation canals which flow northward (El- Ebrahimiya and Bahr Youssef) and their tributaries in different directions.

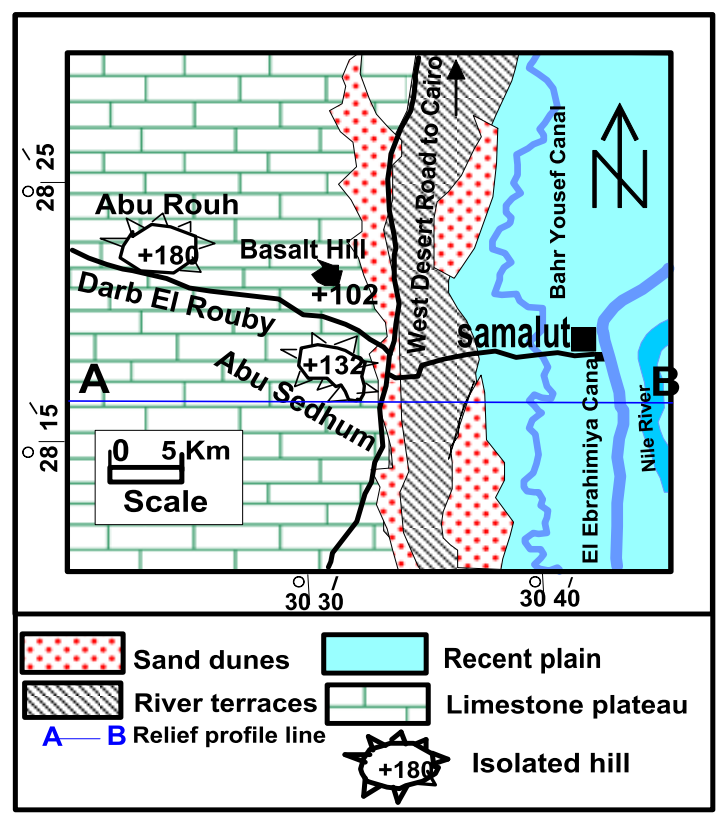

Fig. 2: The geomorphologic units.

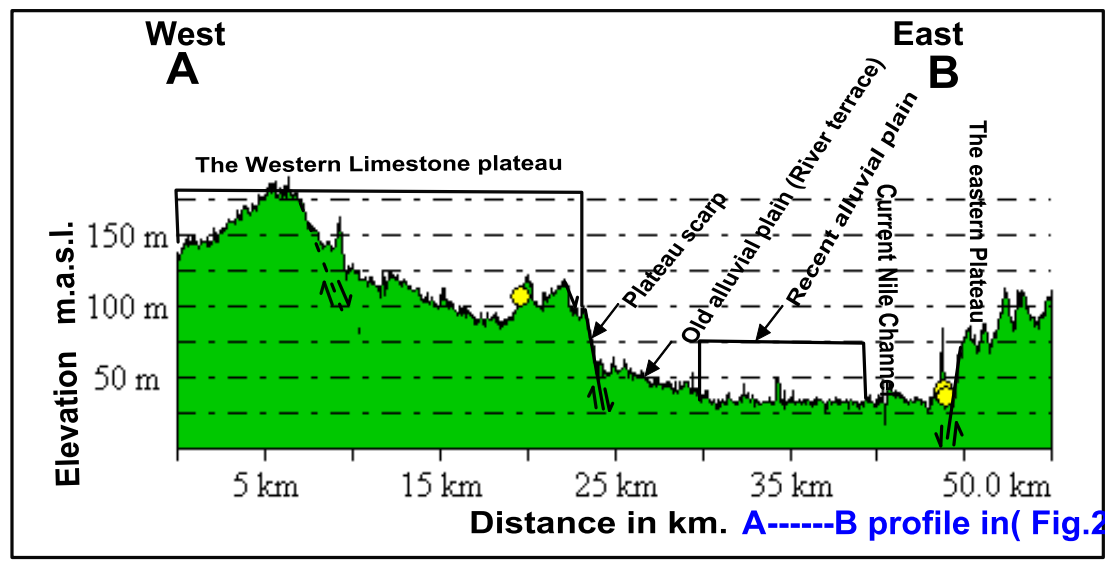

Fig. 3: Topographic features profile (Digital elevation model).

\section{Geologic setting}

The geologic succession of the investigated area and its vicinities are previously studied by many authors, among them are; Said ${ }^{[1,2]}$, Ezzat ${ }^{[3]}$, Khalifa [4], Mansour and Philobbos [5], Strougo [6], El Sayed [7], Abdel Aziz ${ }^{[8]}$ and Abdel Baki ${ }^{[9]}$. The geologic setting in the area of study is discussed as based on the previous works, field investigations, geologic map ${ }^{[10]}$ and the subsurface geologic data of the drilled wells (Fig. 4). The stratigraphic succession in the area of study is given from older to younger as follows:

\section{1- Eocene rocks}

The Eocene rock units are the oldest exposed rocks in the area (Fig. 5). Upon the positive structural elements, the Eocene succession may be subjected to weathering and erosion activities or deposited with low thickness so, it thins in Nashfa uplift (95.4 m; Nashfa well) (Fig. 6), ${ }^{[11]}$. However, the Eocene rocks thicken along the negative structures, where they deposited with high thickness and have been preserved as in Abu Mahariq graben (534 mNB7-1 well). The thickness of the Eocene increases towards the Nile rift ${ }^{[7]}$. 


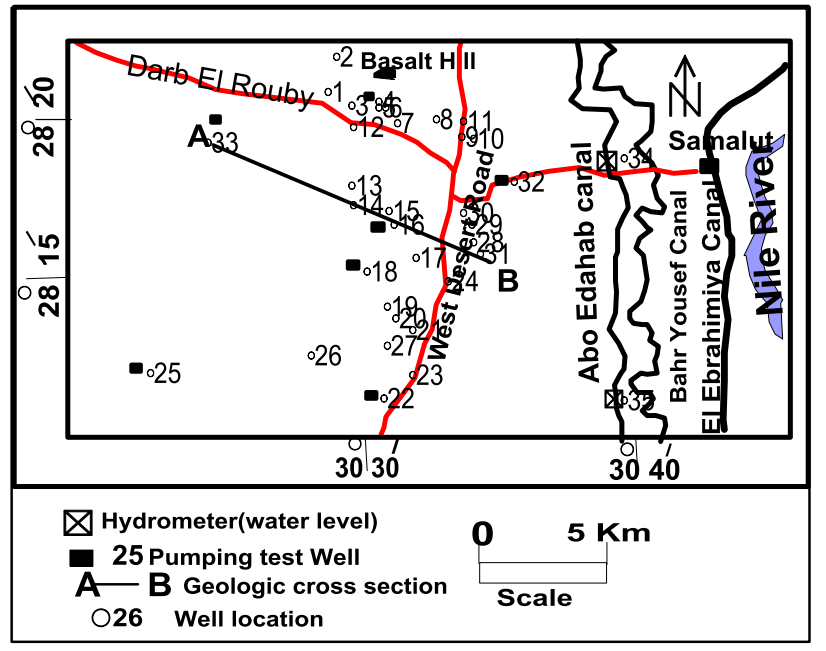

Fig. 4: Well location map of the area of study.

Locally, in the investigated area, the oldest exposed Eocene rocks belong to the Samalot Formation. Samalot section outcrops with thickness about $20 \mathrm{~m}$ and extends in subsurface for about $225 \mathrm{~m}$ (records of penetrated wells). The well logs of the drilled wells (Fig. 7) are used to construct a correlation chart, which reveals that the area is dissected by step faults towards the Nile rift. These faults have throws range between $50 \mathrm{~m}$ and $35 \mathrm{~m}$
Eastward (Fig. 8). Samalot Formation is composed of soft, massive, cavernous and chalky limestone with shale and sand intercalations. It is characterized by the presence of Nummulite Gizahensis. It belongs to Middle Eocene times ${ }^{[12]}$.

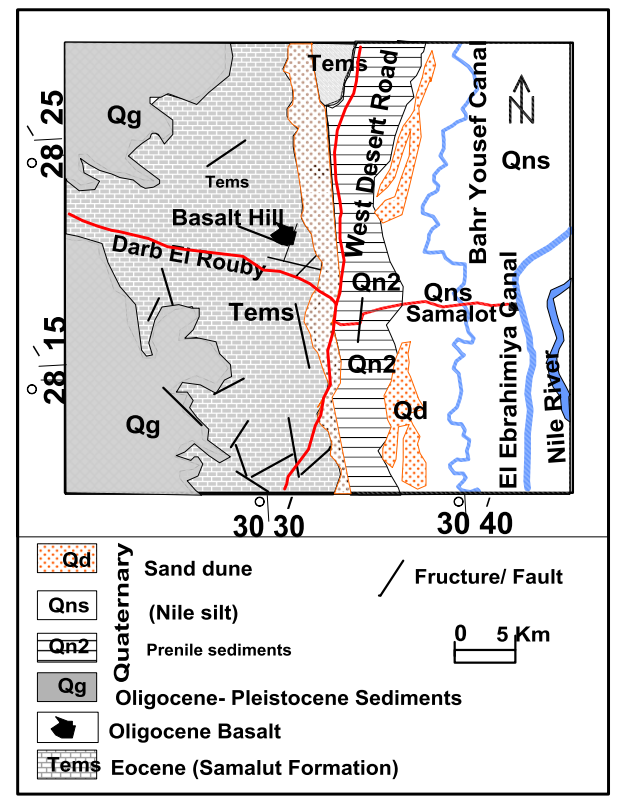

Fig. 5: Geological map of the area of study, After Conoco ${ }^{[10]}$.

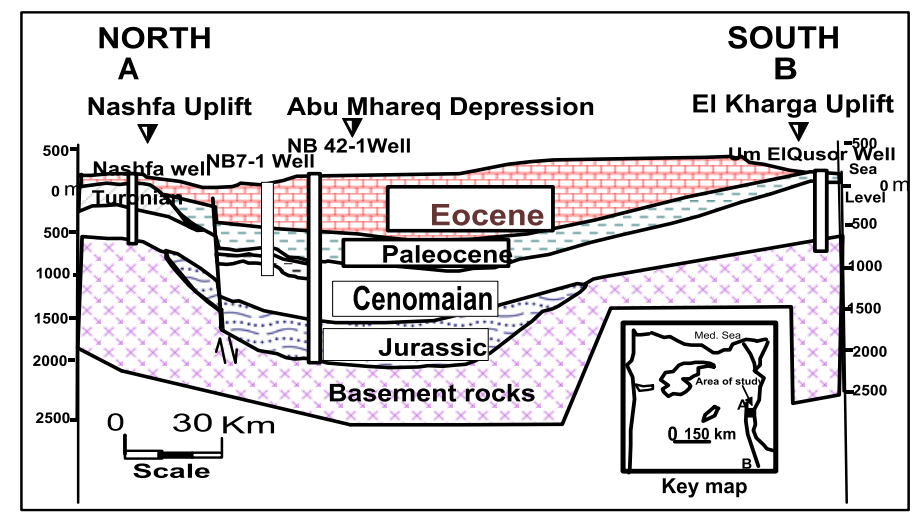

Fig. 6: Geologic cross-section, Nashfa-Um El Qusour (Modified after Joint Venture Qattara) ${ }^{[11]}$.

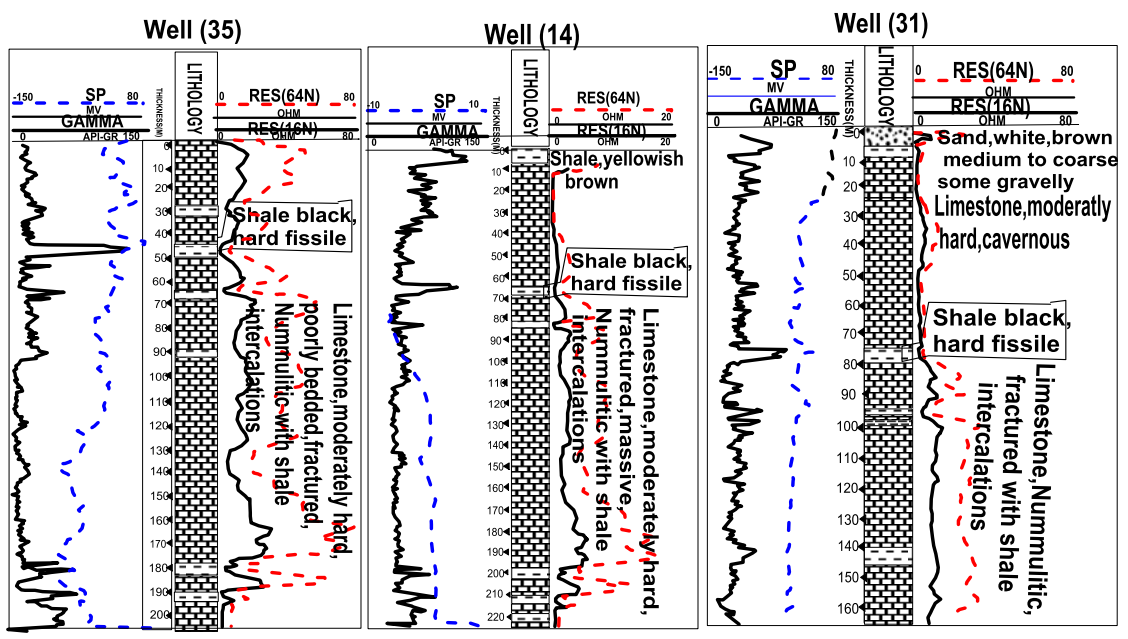

Fig. 7: Well logging charts of the drilled wells in the area of study (ECDC,2009). 


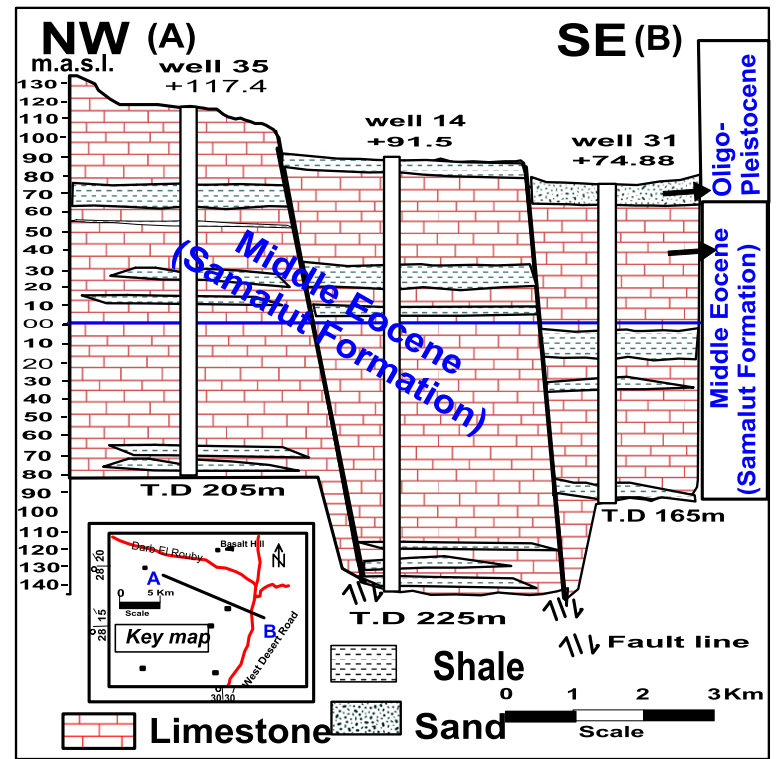

Fig. 8: NW-SE geologic cross section, the area of study.

\section{2- Oligocene rocks}

The Oligocene rocks in the investigated area occur in the northeastern part as basaltic extrusions. These volcanic extrusions are most probably of Oligocene age ${ }^{[8]}$. The Basalt rocks in the area of study are known as the Tertiary volcanics ${ }^{[10]}$. They are exposed in Darb Elrouby (Basalt hill) with an elevation reaches about 20 $m$ above the landscape.

\section{3- Oligocene - Pleistocene rocks units}

Oligocene -Pleistocene sediments are scattered covering the low parts on the surface of the Eocene limestone. To the west of longitude $30^{\circ} 25^{\prime} \mathrm{E}$, Oligocene - Pleistocene sediments occur continuously covering the Eocene limestone (Fig. 5). It is composed of calcareous gravels, sands medium to coarse white to reddish, ferruginous.

\section{2- Quaternary deposits}

The Quaternary deposits overly the Eocene rocks with unconformable plain on the low lands especially along the far eastern and western parts. These sediments form the Neo-Nile terraces ${ }^{[1]}$. They are composed of graded sands changed to calcareous gravels at top. More eastward, these terraces are covered by the Holocene Nile silty clay deposits which extend to the recent current Nile river channel. Sand dunes and sand sheets are stretched along the eastern parts of the area in the form of longitudinal chains. They are composed of fine yellow sands, sometimes calcareous.

Structurally, the area of study comprises a part of the Nile basin which is mainly affected by the structural setting of the Red Sea and the Gulf of Suez (NW-SE trend). Abdel Baky ${ }^{[9]}$, referred to the presence of water bearing buried channels run through structural grabens along (X-X') profile of NW-SE trend immediately adjacent to the western borders of the study area (Fig. 9). These buried channels extend northwestward along Abu Mhareq depression and southward to intercept the Nile River at south Assuit area. Also, he referred to other water bearing buried channels along the profiles
J-J', K-K' and L-L' of NE-SW and E-W trends (Fig. 10). These grabens occupy the west and southwestern part of the investigated area. Darb ElRouby road runs northwest along highly disturbed area. It includes the remnants of the faulted blocks which are dotted by the isolated hills as Abu Rouh and Abu Sedhom. The volcanic extrusions in Darb ElRouby seem to be contemporaneous with the NW-SE fault system, which took place in late Oligocene time ${ }^{[8]}$. The NW-SE normal faults have throws range between $50 \mathrm{~m}$ and $35 \mathrm{~m}$ to the East (Fig. 8). Also the NE-SW and E-W normal faults occur. These fractured networks represent good conduits for store and transmit groundwater.

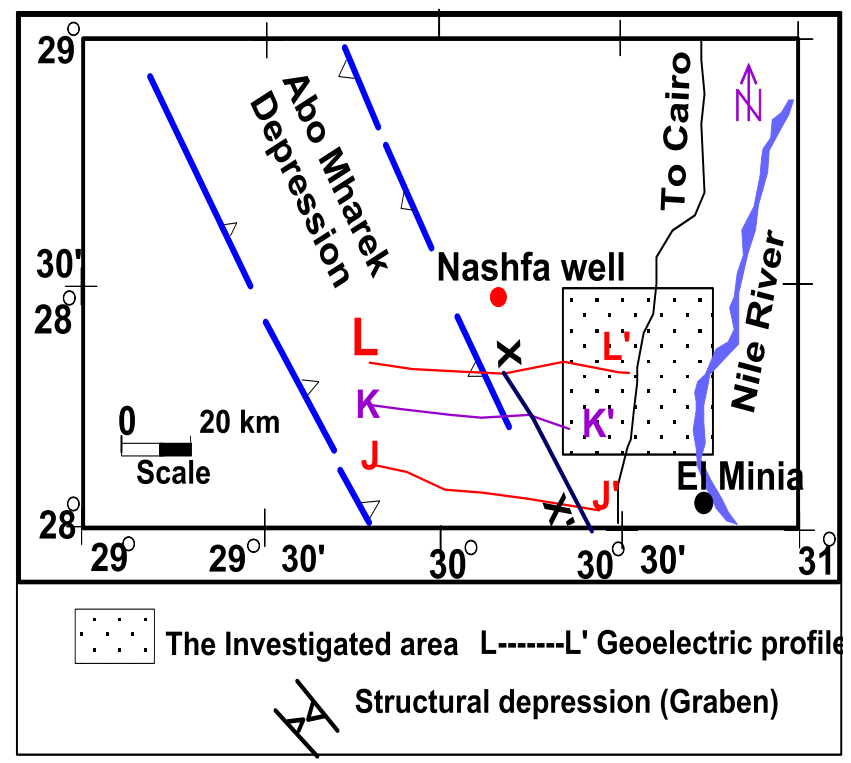

Fig. 9: Key map, Modified after Ezzat ${ }^{[1]}$.

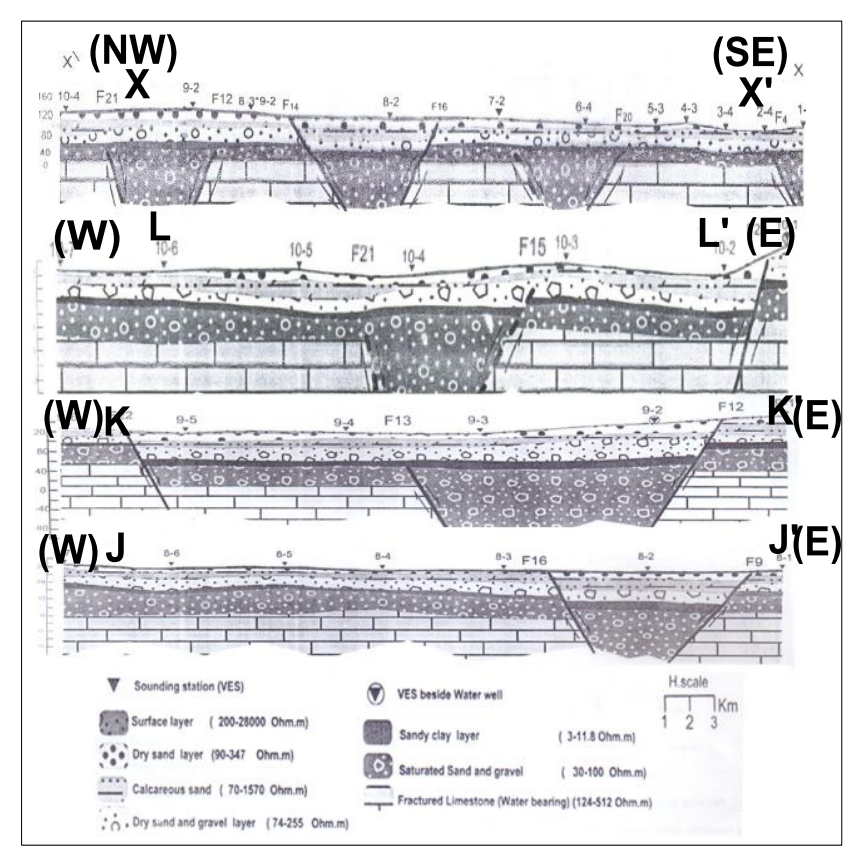

Fig. 10: Geoelectric profiles (mapped in Fig. 9), After Abdel Baki ${ }^{[9]}$. 


\section{Hydrogeological setting}

El Minia area was previously subjected to hydrogeological and hydrogeochemical studies by many authors among them are; El Sayed ${ }^{[7]}$, IWACO/RIGW [13], Abou Heleika and Niesner [14], El Kashouty ${ }^{[15]}$, Shabana ${ }^{[16,17]}$. The previous works of these authors are considered. The groundwater in the area of study is exploited only from the Samalot fractured limestone aquifer. Depending on the subsurface geologic data of the drilled wells (Table 1), the measured groundwater levels, the pumping tests data, the hydrogeological conditions are discussed as follows:

\section{1- Aquifer characteristics}

The maximum thickness of Samalot fractured limestone aquifer in west El Minia area reaches 534.9 m (NB7-1). The bottom of the aquifer is the Paleocene shale (Fig. 6). In the area of study, the drilled wells tapping this aquifer have depths range between $50 \mathrm{~m}$ and $225 \mathrm{~m}$ (Table 1). The aquifer occurs under free water table condition, where the water level in the wells occurs under the top surface of the aquifer (Fig. 11). The subsurface NW-SE and NE-SW water bearing buried channels and its related fractured zones store and transmit groundwater. Moreover, the field investigation recorded partial and complete losses of the mud fluid during the hydraulic rotary drilling of the water wells in this aquifer. This attributes to the presence of subsurface fractures and caves.

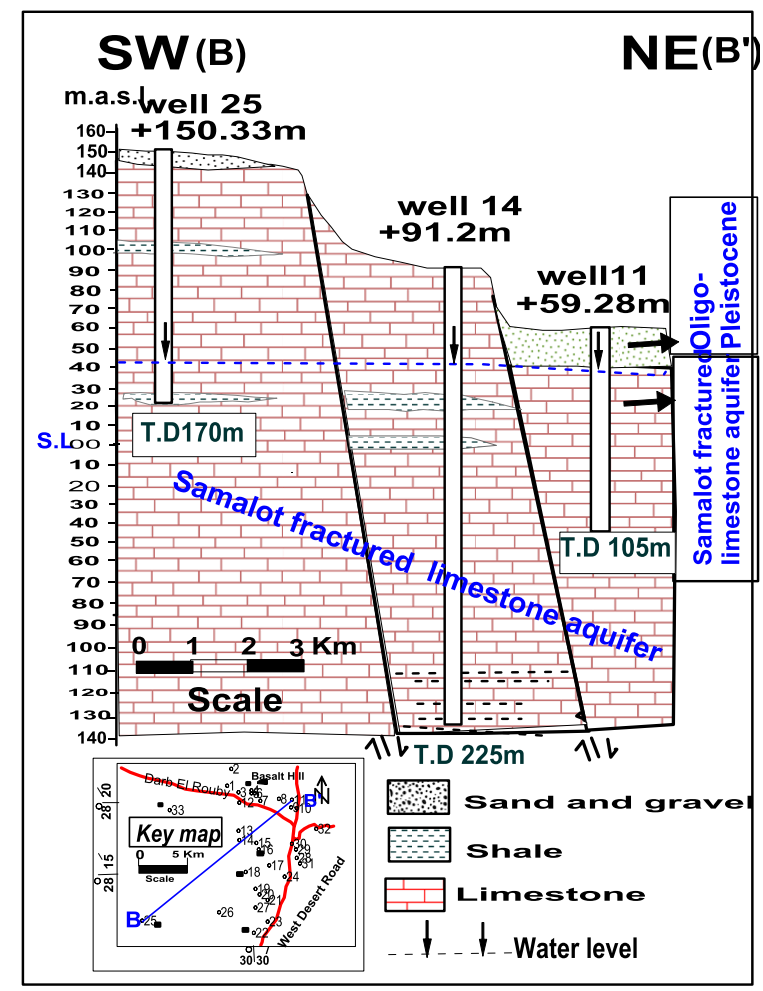

Fig. 11: NE-SW geologic cross section, the area of study.

\section{2- Groundwater flow}

The groundwater levels in the area of study are measured. The depth to water ranges between $109.43 \mathrm{~m}$.to the west and $14.30 \mathrm{~m}$. to the east. There is no surface recharging boundary occur at west of the area of study. The subsurface NW-SE and NE-SW water bearing buried channels and its related fractured zones act as positive boundary. It may be the source of recharge of the Samalot fractured limestone aquifer in the area of study from the west. (Fig. 12) shows that the groundwater flows to the east and northeast of the study area. This situation means that Abo Edahab and Bahr Youssef canals are acting as drains. Previously, El Kashouty ${ }^{[15]}$, revealed that the groundwater flows towards the eastern part (due the Bahr Youssef and River Nile), which are discharging areas rather than recharging ones. The hydraulic gradient (I) along the water level profile C-C' (Fig. 13) increases from $0.25 \mathrm{~m} / 1000 \mathrm{~m}$ to $0.71 \mathrm{~m} / 1000 \mathrm{~m}$, where the equipotential lines became closely spaced (high gradient-I) towards the northeastern areas, (Fig. 12). The equation of Darcy $Q=K I A$, concerning the flow rate $(\mathrm{Q})$ across a sectional area $(\mathrm{A})$ is proportional to the hydraulic conductivity $(\mathrm{K})$ and the hydraulic gradient (I). Accordingly, the flow rate (Q) increases due northeastern areas, which are also characterized by highly discharges.

The water levels in two wells (10 and 17) are measured periodically every 6 months. The estimated annual drop in water level increases eastward from $0.5 \mathrm{~m}$ to $2.45 \mathrm{~m}$ (Fig. 14). The maximum drop $(2.45 \mathrm{~m})$ lies along northeastern parts due to intensive discharges in order to meet the demand of irrigation of the reclaimed land.

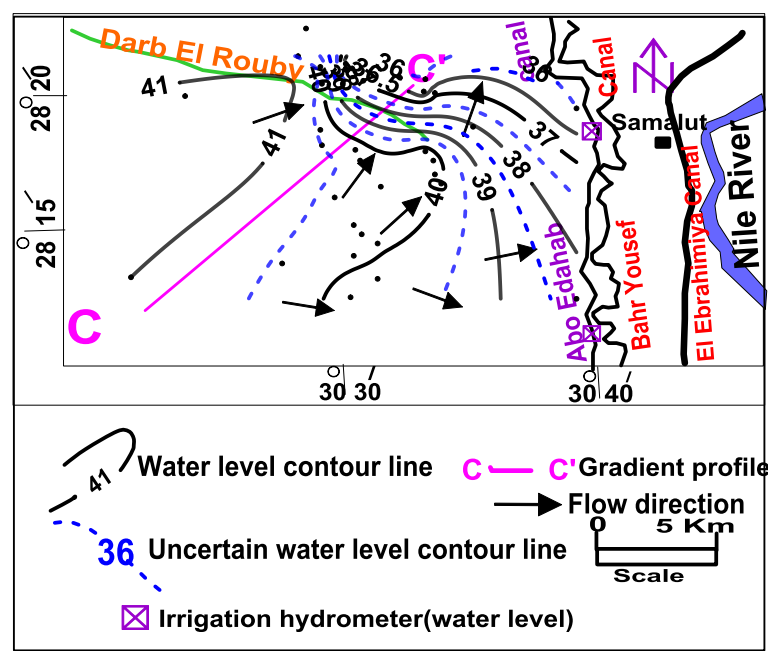

Fig. 12: Water table contour map, the area of study (records of august 2015).

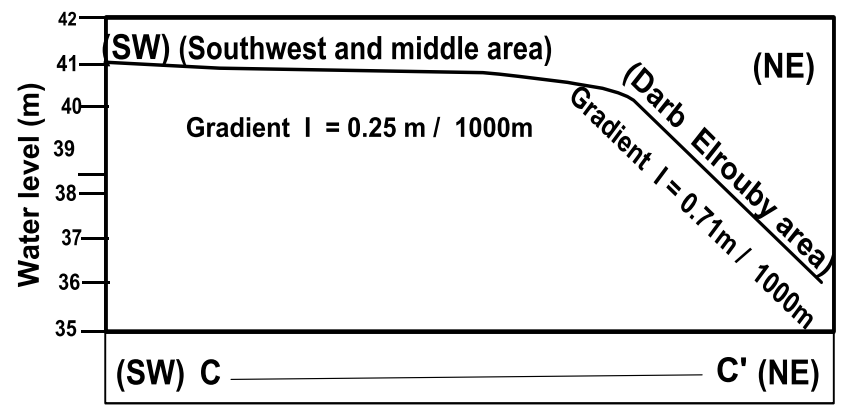

Fig. 13: SW-NE, groundwater gradient profile( C---C'). 
Table 1: Field measurements of the drilled water wells, west Samalot, El Minia Governorate, Egypt.

\begin{tabular}{|c|c|c|c|c|c|c|c|}
\hline \multirow{2}{*}{$\begin{array}{c}\text { Well } \\
\text { No. } \\
1 \\
\end{array}$} & \multicolumn{3}{|c|}{ Coordinates } & \multirow{2}{*}{\begin{tabular}{|c|}
$\begin{array}{c}\text { Ground } \\
\text { elevation } \\
\text { m.a.s.l. }\end{array}$ \\
97.15 \\
\end{tabular}} & \multirow{2}{*}{$\begin{array}{c}\begin{array}{c}\text { Depth to } \\
\text { water/m }\end{array} \\
56.69 \\
\end{array}$} & \multirow{2}{*}{$\begin{array}{c}\begin{array}{c}\text { Water level } \\
\text { m.a.s.l. }\end{array} \\
\mathbf{4 0 . 4 6} \\
\end{array}$} & \multirow{2}{*}{$\begin{array}{c}\begin{array}{c}\text { Total Depth } \\
\text { m. }\end{array} \\
120\end{array}$} \\
\hline & $\mathrm{N} 28^{\circ} \quad 2$ & $20^{\prime} 46^{\prime \prime}$ & E $30^{\circ} 28^{\prime} 42^{\prime \prime}$ & & & & \\
\hline 2 & $\mathbf{N} 28^{\circ}$ & $21^{\prime} 50^{\prime \prime}$ & E $30^{\circ} \quad 28^{\prime} 58^{\prime \prime}$ & 98.48 & 58.33 & 40.15 & 200 \\
\hline 3 & N $28^{\circ}$ & $20^{\prime} 21^{\prime \prime}$ & E $30^{\circ} \quad 29^{\prime} 32^{\prime \prime}$ & 86.95 & 46.59 & 40.36 & 80 \\
\hline 4 & $\mathrm{~N} 28^{\circ}$ & $20^{\prime} 26^{\prime \prime}$ & E $30^{\circ} 30^{\prime} \quad 27^{\prime \prime}$ & 77.8 & 40.91 & 36.17 & 105 \\
\hline 5 & N 28 ${ }^{\circ}$ & $20^{\prime} 17^{\prime \prime}$ & E $30^{\circ} 30^{\prime} 30^{\prime \prime}$ & 75.87 & 39.70 & 36.17 & 80 \\
\hline 6 & $\mathrm{~N} 28^{\circ} 2$ & $20^{\prime} 16^{\prime \prime}$ & E 30 $30^{\prime} 43^{\prime \prime}$ & 75.09 & 38.84 & 36.21 & 100 \\
\hline 7 & N 28 ${ }^{\circ}$ & $19^{\prime} 48^{\prime \prime}$ & E $30^{\circ} 31^{\prime} 10^{\prime \prime}$ & 72.88 & 36.12 & 36.76 & 104 \\
\hline 8 & N 28 ${ }^{\circ}$ & $19^{\prime} 54^{\prime \prime}$ & E 30 $32^{\prime} 32^{\prime \prime}$ & 66.69 & 30.52 & 36.17 & 110 \\
\hline 9 & N 28 ${ }^{\circ}$ & $19^{\prime} 22^{\prime \prime}$ & E $30^{\circ} 33^{\prime} \quad 26^{\prime \prime}$ & 60 & 23.87 & 36.13 & 75 \\
\hline 10 & N 28 ${ }^{\circ}$ & $19^{\prime} 18^{\prime \prime}$ & E 30 $33^{\prime} 51^{\prime \prime}$ & 57.35 & 20.45 & 36.9 & 100 \\
\hline 11 & N 28 1 & $19^{\prime} 52^{\prime \prime}$ & E $30^{\circ} 33^{\prime} 30^{\prime \prime}$ & 59.28 & 22.68 & 36.56 & 105 \\
\hline 12 & N 28 ${ }^{\circ}$ & $18^{\prime} 50^{\prime \prime}$ & E $30^{\circ} \quad 29^{\prime} 35^{\prime \prime}$ & 86.29 & 46.00 & 40.29 & 120 \\
\hline 13 & $\mathbf{N} 28^{\circ}$ & $17^{\prime} 54^{\prime \prime}$ & E $30^{\circ} 29^{\prime} 31^{\prime \prime}$ & 94.92 & 54.41 & 40.41 & 225 \\
\hline 14 & $\mathbf{N} 28^{\circ}$ & $17^{\prime} 18^{\prime \prime}$ & E $30^{\circ} 29^{\prime} 36^{\prime \prime}$ & 91.2 & 50.71 & 40.49 & 225 \\
\hline 15 & N 28 ${ }^{\circ} 1$ & $17^{\prime} 06^{\prime \prime}$ & E 30 $30^{\prime} 49^{\prime \prime}$ & 92.49 & 52.13 & 40.36 & 140 \\
\hline 16 & N 28 ${ }^{\circ}$ & $16^{\prime} 41^{\prime \prime}$ & E 30 $31^{\prime} 02^{\prime \prime}$ & 86.69 & 45.81 & 40.88 & 145 \\
\hline 17 & N 28 1 & $15^{\prime} 41^{\prime \prime}$ & E $30^{\circ} 31^{\prime} 47^{\prime \prime}$ & 76.81 & 36.50 & 40.31 & 150 \\
\hline 18 & N 28 ${ }^{\circ}$ & $15^{\prime} 16^{\prime \prime}$ & E $30^{\circ} 30^{\prime} \mathbf{0 3}^{\prime \prime}$ & 91.66 & 50.685 & 40.345 & 120 \\
\hline 19 & N 28 1 & $14^{\prime} 08^{\prime \prime}$ & E $30^{\circ} 30^{\prime} 47^{\prime \prime}$ & 97.54 & 57.295 & 40.245 & 125 \\
\hline 20 & N 28 ${ }^{\circ}$ & $13^{\prime} 48^{\prime \prime}$ & E 30 $31^{\prime} 06^{\prime \prime}$ & 92.89 & 52.66 & 40.23 & 110 \\
\hline 21 & N 28 ${ }^{\circ}$ & $13^{\prime} 25^{\prime \prime}$ & E $30^{\circ} 31^{\prime} 41^{\prime \prime}$ & 91.70 & 51.64 & 40.06 & 115 \\
\hline 22 & N 28 ${ }^{\circ}$ & $11^{\prime} 20^{\prime \prime}$ & E $30^{\circ} 30^{\prime} 39^{\prime \prime}$ & 108.27 & 68.49 & 39.78 & 150 \\
\hline 23 & N 28 1 & $12^{\prime} 03^{\prime \prime}$ & E $30^{\circ} 31^{\prime} 40^{\prime \prime}$ & 96.38 & 56.48 & 39.9 & 90 \\
\hline 24 & $\mathrm{~N} 28^{\circ}$ & $14^{\prime} 55^{\prime \prime}$ & E $30^{\circ} 32^{\prime} \quad 55^{\prime \prime}$ & 74.88 & 34.685 & 40.195 & 100 \\
\hline 25 & $\mathrm{~N} \mathrm{28}^{\circ} \quad 1$ & 12'07" & E $30^{\circ} \quad 22^{\prime} 24^{\prime \prime}$ & 150.33 & 109.43 & 41 & 170 \\
\hline 26 & $\mathrm{~N} 28^{\circ} \quad 1$ & $12^{\prime} 38^{\prime \prime}$ & $\begin{array}{lll}\text { E } 30^{\circ} & 28^{\prime} & 05^{\prime \prime}\end{array}$ & 121.04 & 80.62 & 40.42 & 70 \\
\hline 27 & N 28 ${ }^{\circ}$ & $12^{\prime} 38^{\prime \prime}$ & E $30^{\circ} \quad 28^{\prime} \quad 05^{\prime \prime}$ & 111.75 & 71.655 & 40.095 & 110 \\
\hline 28 & N 28 ${ }^{\circ}$ & $16^{\prime} 07^{\prime \prime}$ & E $30^{\circ} 33^{\prime} 49^{\prime \prime}$ & 62.02 & 21.81 & 40.21 & 60 \\
\hline 29 & N 28 ${ }^{\circ}$ & $16^{\prime} 40^{\prime \prime}$ & E 30 $33^{\prime} 45^{\prime \prime}$ & 62.82 & 22.55 & 40.27 & 75 \\
\hline 30 & $\mathrm{~N} \mathrm{28}^{\circ}$ & $17^{\prime} 03^{\prime \prime}$ & E 30 $33^{\prime} 27^{\prime \prime}$ & 62.94 & 22.70 & 40.24 & 70 \\
\hline 31 & $\mathrm{~N} 28^{\circ}$ & $15^{\prime} 48^{\prime \prime}$ & $\begin{array}{lll}\text { E } 30^{\circ} & 34^{\prime} & \mathbf{0 3}^{\prime \prime}\end{array}$ & 60.31 & 20.30 & 40.01 & 215 \\
\hline 32 & N 28 1 & $18^{\prime} 26^{\prime \prime}$ & E $30^{\circ} \quad 25^{\prime} 56^{\prime \prime}$ & 54.58 & 14.30 & 40.28 & 50 \\
\hline 33 & N 28 ${ }^{\circ}$ & $17^{\prime} 42^{\prime \prime}$ & E $30^{\circ} 35^{\prime} 16^{\prime \prime}$ & 117.4 & 76.6 & 40.8 & 205 \\
\hline 34 & $\mathrm{~N} 28^{\circ}$ & $18^{\prime} 59^{\prime \prime}$ & E $30^{\circ} 39^{\prime} 12^{\prime \prime}$ & AboEdahab & hydrometer & 36 & \\
\hline 35 & $\mathrm{~N} 28^{\circ}$ & $11^{\prime} 20^{\prime \prime}$ & E $30^{\circ} 39^{\prime} 12^{\prime \prime}$ & Abo Edahab & hydrometer & 38.25 & \\
\hline
\end{tabular}

\section{3- Aquifer hydraulic parameters}

Six pumping and recovery tests with constant discharging rate are operated. These tested wells cover most of the investigated area. During the pumping tests times, it is easy to pull down the water level measuring electrode, so the drawdown levels in all these tests are recorded along the pumped well. However, during the recovery times, it is difficult to pull up water level measuring electrode, thus the measuring of recovery levels cannot be available except only in two wells (16 and 18). Greene et al ${ }^{[18]}$ applied the dual-porosity solution to obtain the parameters of the Madison limestone aquifer. Using the same drawdown data, Kresic (19) revealed that a simple solution of CooperJacob (20) for both the early and the late pumping test drawdown data of the Madison limestone aquifer give values of transmissivity and storativity similar to the dual-porosity solution of Greene et al ${ }^{[18]}$. Shabana ${ }^{[17]}$ 
applied the solution of Cooper-Jacob straight line ${ }^{[20]}$ to determine the parameters of the Samalot fractured limestone aquifer in Wadi Tarfa east El Minia area. Herein, the author applies the solution of Cooper-Jacob straight line ${ }^{[20]}$ to estimate approximately the values of aquifer parameters. The records of pumping and recovery tests are graphically represented (Fig. 15). Some pumping and recovery curves show two segments reflecting the nature of the fractured and Karast aquifers which are having variable permeability. In this case, the slope of the straight line decreases to give another segment as in wells Nos. (16, 18 and 33). The other curves show one segment indicting the recharging from one single fracture as in wells Nos. (4, 22 and 25). The equation of Cooper and Jacob ${ }^{[19]}$ is used for the estimation of transmissivity values during pumping (Tp) and recovery $(\mathrm{Tr}) ;=\frac{2.3 Q}{4 \pi \Delta S}$, Where $\mathrm{Q}$ is the constant discharge; $\Delta S$ is the drawdown per one log cycle. The calculated (T) values are introduced in (Table 2). Gheorghe [21] classified the aquifer potentiality according to the values of transmissivity (Table 3). Figure 16 shows the distribution of the transmissivity (T) along the area of study, where the high potentiality values (4394.9 $\left.\mathrm{m}^{2} / \mathrm{d}-3515.929 \mathrm{~m}^{2} / \mathrm{d}\right)$ exist along the eastern highly dissected area. While the moderate and low potentiality $\left(274.68 \mathrm{~m}^{2} / \mathrm{d}-15.13 \mathrm{~m}^{2} / \mathrm{d}\right)$ present in the western low fracture density parts.

To estimate a real value of the specific yield, the records of water levels during the test have to be measured along the observation well. The present pumping tests were observed and recorded along the discharged wells. Therefore, the effective radius of the test well cannot be determined ${ }^{[22]}$ and the specific yield cannot be obtained. On other wards, the recovery curves may be used to give the percent of specific yield during pumping and recovery according to the formula; $\log \left(t / t^{\prime}\right)_{0}=\mathrm{s} / \mathrm{s}^{\prime}{ }^{[23]}$. Where, $\left(t / t^{\prime}\right)_{0}$ : is the value of $\left(t / t^{\prime}\right)$ at zero residual drawdown, $S$ : specific yield during pumping, $S^{\prime}$ : specific yield during recovery. The calculated value of $\log \left(\mathrm{t} / \mathrm{t}^{\prime}\right)_{0}$ is equal $\log 10=1$ in the areas of well (Nos.16 - 18). So, $\mathrm{s} / \mathrm{s}^{\prime}=1$, indicating the same value of storage during pumping and recovery of the same well.

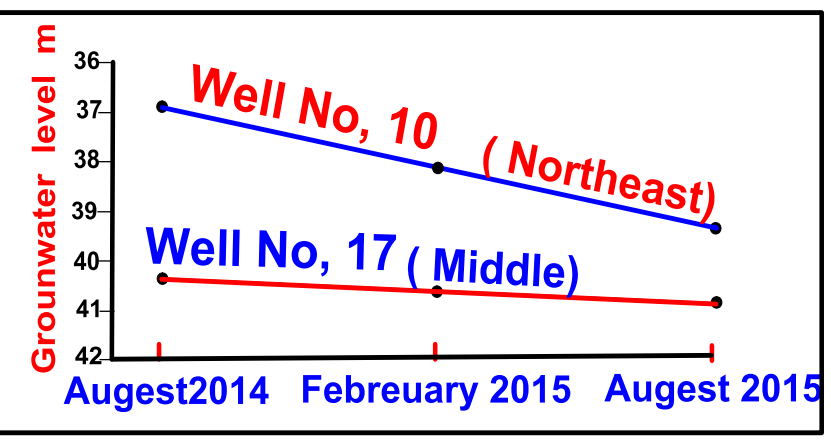

Fig. 14: Annual drop in groundwater level.

\section{4- Well efficiency}

Two step pumping tests with three changeable discharging rates are carried out on two wells (Nos. 22 33). Every test extends for three steps (Table 4). The time-drawdown records are graphically represented (Fig. 17) in order to estimate the following:

A- The coefficient of losses in drawdown due to well screen, pumping component and well development (well loss - C).

B- The coefficient of losses in drawdown due to aquifer formation nature (formation loss- B).

C- Prediction of the total drawdown in the water level in the well during pumping in case of any future increase or change in discharging rate.

D- Well efficiency.

Table 2: Aquifer parameters estimated from pumping and recovery tests for selected drilled groundwater wells, the area of study.

\begin{tabular}{|c|c|c|c|c|c|}
\hline \multirow{3}{*}{ 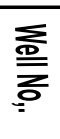 } & \multicolumn{2}{|c|}{ Constant pumping rate $Q \mathrm{~m} 3 /$ day } & \multirow{2}{*}{\multicolumn{3}{|c|}{ Step drawdown tests m3/day }} \\
\hline & \multicolumn{2}{|c|}{ Transmissivity T( m2/day) } & & & \\
\hline & Pumping Tp (m2/day & Recovery $\operatorname{Tr}$ (m2/day) & Well losses (C) $d^{2} / m^{5}$ & Formation losses (B) $d / m^{2}$ & Well efficiency $\%$ \\
\hline 4 & 4394.9 & & & & \\
\hline 16 & 2043.63 & 2062.63 & & & \\
\hline 18 & 1318.47 & 1341.5 & & & \\
\hline 22 & 3515.92 & & $8(10)^{7}$ & $1.2(10)^{4}$ & 78 \\
\hline 25 & 15.13 & & & & \\
\hline 33 & 274.68 & & $9(10)^{-4}$ & $63(10)^{3}$ & 77 \\
\hline
\end{tabular}

Table 3: Classification of aquifer potentiality ${ }^{[21]}$.

\begin{tabular}{|l|c|}
\hline Aquifer potentiality & Transmissivity ( T ) m2/day \\
\hline Negligable potentiality & Less than 5 \\
\hline Very low potentiality & $0.5-5$ \\
\hline Low potentiality & $5-50$ \\
\hline Moderate potentiality & $50-500$ \\
\hline High potentiality & Over 500 \\
\hline
\end{tabular}



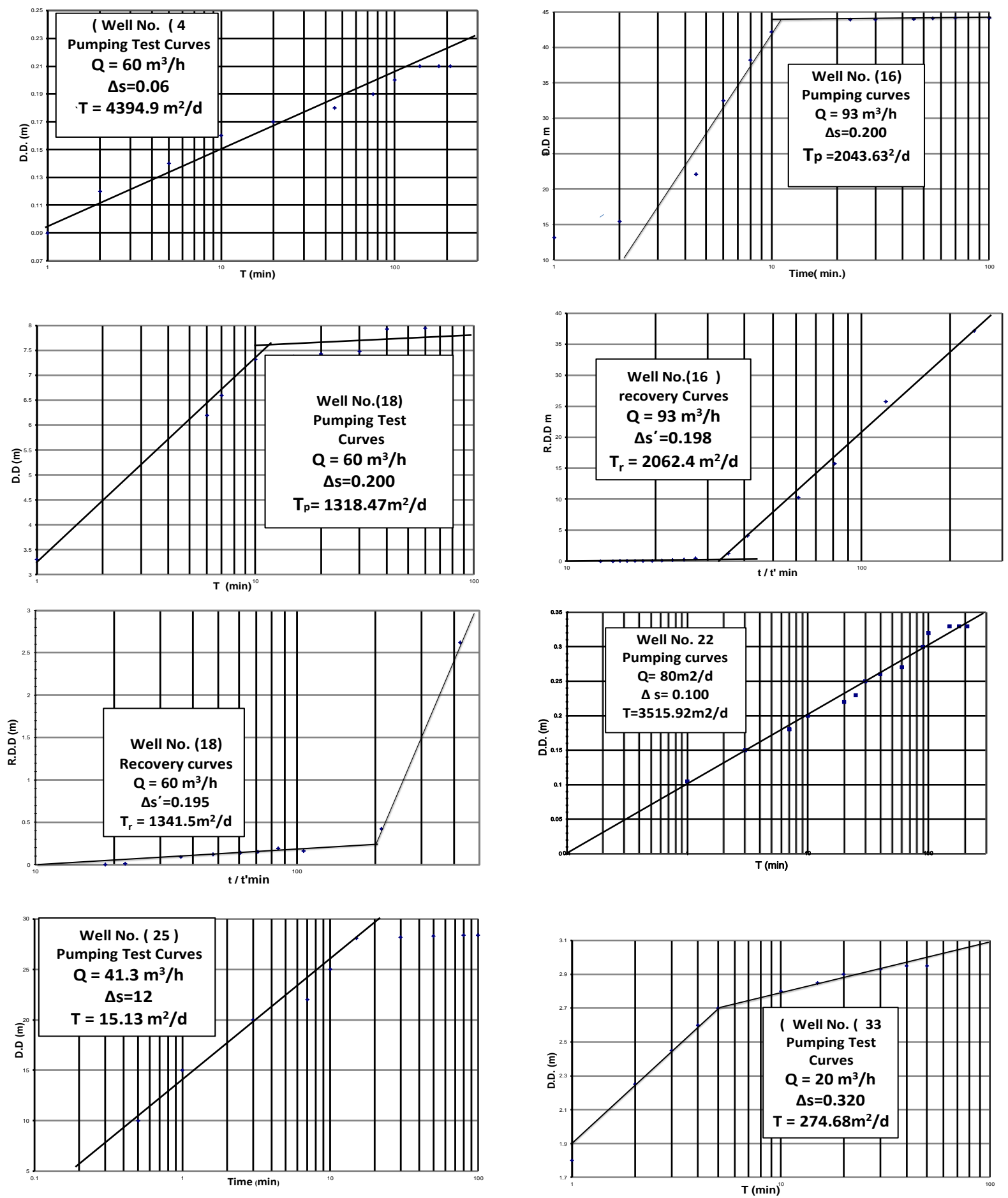

Fig. 15: Constant discharge pumping and recovery tests curves.

Applying Walton ${ }^{[24]}$ equation; $\mathrm{S}=\mathrm{BQ}+\mathrm{CQ}$ where, $\mathrm{S}$ : the total drawdown in the well during pumping (m). Q: the rate of discharge during pumping $\left(\mathrm{m}^{3} / \mathrm{h}\right)$. C: the coefficient of well losses $\left(\mathrm{d} / \mathrm{m}^{2}\right)$.

B: The coefficient of formation losses $\left(\mathrm{d}^{2} / \mathrm{m}^{5}\right)$.

The fractured aquifers resemble the anisotropic granular ones because of the fracture density is not always well distributed. Also, the drilled wells partially penetrate the aquifer. In such cases, use of total screen or open well bore length as a substitute for total aquifer thickness will give reasonably reliable results, ${ }^{[22]}$.
The calculated value of the coefficients of well loss (C) and formation loss (B) in the screened well (No. 33), is more than that in the open hole well (No. 22) (Table 2). Rorabaugh ${ }^{[25]}$ defined the well efficiency as the ratio of the well loss $(B Q)$ to the drawdown inside the well (s). The efficiency of a well depends upon the construction features of the well, the pumping rate, development of the well and the hydrogeological characteristics of the aquifer. The efficiency of a well is governed largely by the magnitude of well loss ${ }^{[26]}$. The estimated well efficiency values (Table 2) have no marked difference in 
Table 4: Records of step drawdown tests, wells no. 22 and 33, the area of study.

\begin{tabular}{|c|c|c|c|c|}
\hline Well No. & Step No. & $\begin{array}{c}\operatorname{Discharge}(Q) \\
\text { m3/d }\end{array}$ & $\begin{array}{c}\text { Drawdown (S) } \\
(\mathbf{m})\end{array}$ & $\begin{array}{c}\text { Specificic Drawdown } \\
\text { S/Q d/m } / \mathrm{m}^{2} \\
\end{array}$ \\
\hline \multirow{3}{*}{22} & 1 & 744 & 0.05 & $0.67(10)^{-4}$ \\
\hline & 2 & 1680 & 0.22 & $1.34(10)^{-4}$ \\
\hline & 3 & 1920 & 0.30 & $1.54(10)^{-4}$ \\
\hline \multirow{3}{*}{33} & 1 & 408 & 28.30 & $69(10)^{-3}$ \\
\hline & 2 & 504 & 38.20 & $76(10)^{-3}$ \\
\hline & 3 & 600 & 48.25 & $81(10)^{-3}$ \\
\hline
\end{tabular}

the well efficiency of the unscreened well no. 22 and screened well no. 33. The efficiency of a well in an aquifer having a high transmissibility is affected by well loss to a greater degree than the efficiency of a well in an aquifer having a low transmissibility ${ }^{[26]}$. Accordingly, the calculated efficiency of the screened well (No. 33) is not largely affected by well loss $(\mathrm{C})$ because of the low transmissivity value in the area of the well. Due to absence of a screen having a greater per cent of open area with respect to the total surface area of the screen cylinder and a sufficient development for the drilled wells in the fractured limestone aquifer in the study area, it is preferred to let the productive wells as open holes without screens to avoid the effects of well losses (c).

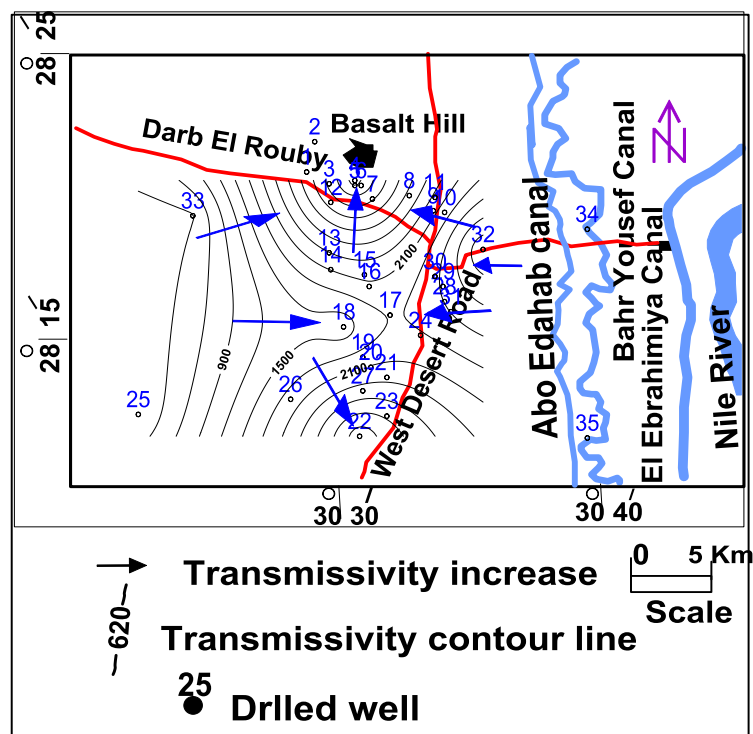

Fig. 16: Transmissivity isolines map, Samalot Formation aquifer, the area of study.

\section{Hydrochemical aspects}

The chemical characteristics of the groundwater are determined through the chemical analysis of 33 water samples according to Hem ${ }^{[26]}$ (Table 5). The results are discussed as follows:

1 - The ionic dominance of all samples is $\mathrm{Na}^{+}>\mathrm{Mg}^{+2}>\mathrm{Ca}^{+2} / \mathrm{Cl}^{-}>\mathrm{HCO}_{3}>\mathrm{SO}_{4}{ }^{-2}$ of sodium chloride water type. However, samples No's $(7-9)$ have the order $\mathrm{Na}^{+}>\mathrm{Mg}^{+2}>\mathrm{Ca}^{+2} / \mathrm{SO}_{4}^{-2}>\mathrm{Cl}^{-}>\mathrm{HCO}_{3}$ with sodium sulphate water type. The presence of $\mathrm{NaCl}$ and $\mathrm{Na}_{2} \mathrm{SO}_{4}$ water types refer to the leaching from the marine carbonate and gypseferous shale.
2- Todd ${ }^{[27]}$ classified the total salinity of natural water into four main categories; 0- $1000 \mathrm{mg} / \mathrm{L}$ fresh water; 1000-10000 mg/L brackish water; 10000-1000000 $\mathrm{mg} / \mathrm{L}$ Saline water and more than $100000 \mathrm{mg} / \mathrm{L}$ brine. About $50 \%$ of the water samples show fresh water type, and $50 \%$ are brackish water type. The fractured limestone aquifer in the western River Nile between Beni Suef and El Minia is mainly recharged by the surrounding aquifers and agricultural waste water ${ }^{[15]}$. El-Sayed [16] attributed the higher values of water salinity in southwest Samalut locality to overpumping activity through reclamation projects. Shabana ${ }^{[17]}$ attributed the high salinity in Samalot fractured limestone aquifer east El Minia to the infiltration of return flow after irrigation through shallow depths to the groundwater. In the area of study, the salinity increases Eastward (Fig. 18). This coincides with the flow trends. The use of flood
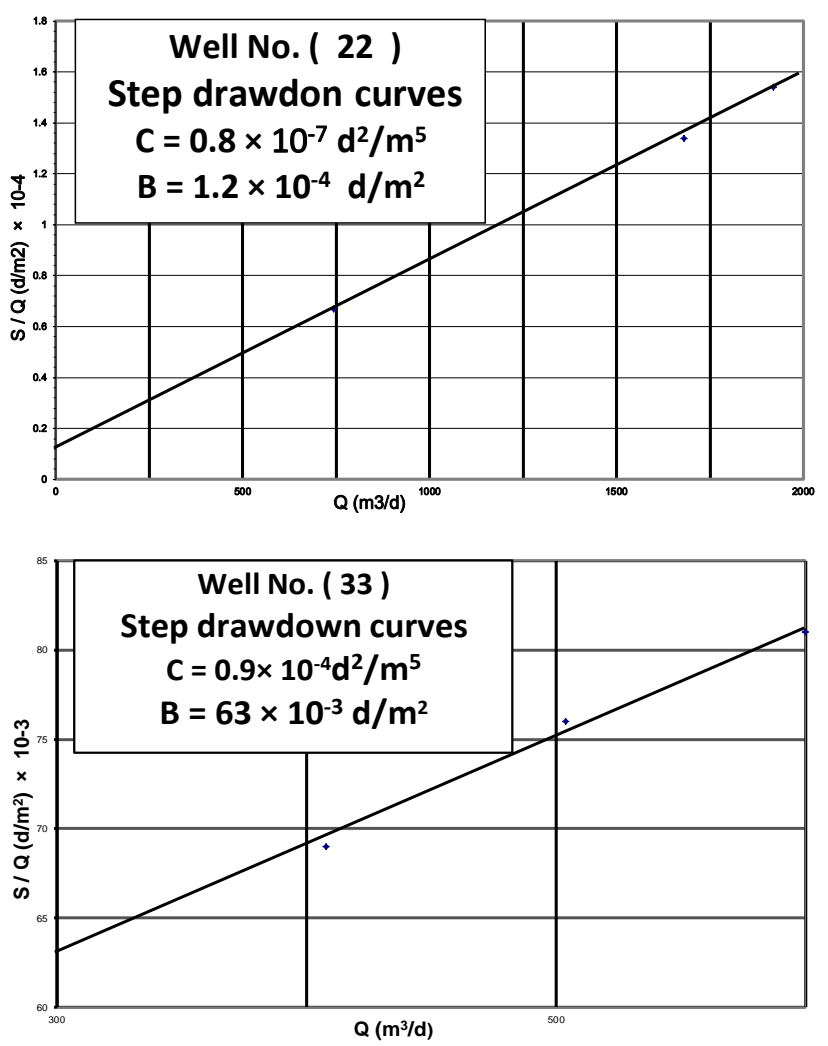

Fig. 17: Step drawdown tests, Changeable drawdown curve, the area of study. 
irrigation system along the eastern parts creates return flow, which leaches the fertilizers and soil minerals into the aquifer through the fractures to the groundwater.

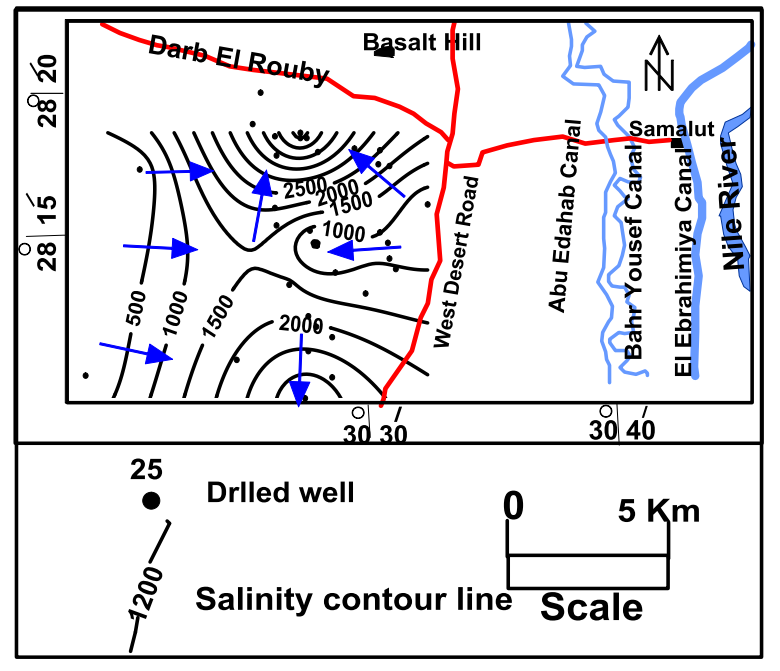

Fig. 18: Isosalinity contour map of the area of study.
Evaluation of groundwater for livestock.

Makee and Wolf ${ }^{[28]}$ set the upper limit of the water concentration for livestock as follows: Poultry (2860 $\mathrm{mg} / \mathrm{l})$; horses (6435 mg/l); Dairy cattle (7105 mg/l); beef cattle $(10100 \mathrm{mg} / \mathrm{l})$ and adult sheep $(219000 \mathrm{mg} / \mathrm{l})$. According to these limits, all the groundwater samples are suitable for livestock.

Suitability of groundwater for irrigation purposes.

The proposed approach by the United States Salinity Laboratory Staff of agriculture ${ }^{[29]}$ is used for determining the suitability of groundwater for irrigation purposes. The diagram is based on the sodium adsorption ratio (SAR) and electrical conductivity (EC) of water (Fig. 19). The results indicate that all water samples lie within classes range between good and intermediate except the sample of well no. 30 lies in the bad one. The water is suitable for agricultural use with certain conditions (Table 6). It can be used with soil management and modern irrigation systems (drip and/or shower) under the restricted drainage. The modern irrigation systems are recommended in these areas to safe water and soil.

Table 5: Chemical analyses data of water samples.

\begin{tabular}{|c|c|c|c|c|c|c|c|c|c|c|c|c|c|c|c|}
\hline \multirow{2}{*}{$\begin{array}{l}\text { Well } \\
\text { No. }\end{array}$} & (EC) & $\mathbf{H}$ & $\mathrm{DS}$ & nits & \multirow[b]{2}{*}{$\mathrm{Ca}^{++}$} & \multirow[b]{2}{*}{$\mathbf{M g}^{++}$} & \multirow[b]{2}{*}{$\mathrm{Na}^{+}$} & \multirow[b]{2}{*}{$\mathbf{K}^{+}$} & \multirow{2}{*}{$\begin{array}{c}\text { Sum } \\
\text { Cat.epm }\end{array}$} & \multirow[b]{2}{*}{$\mathrm{CO}_{3}^{--}$} & \multirow[b]{2}{*}{$\mathrm{HCO}_{3}^{-}$} & \multirow[b]{2}{*}{$\mathrm{SO}_{4}^{--}$} & \multirow[b]{2}{*}{$\mathrm{Cl}^{-}$} & \multirow{2}{*}{$\begin{array}{c}\text { Sum. } \\
\text { Ani.epm }\end{array}$} & \multirow{2}{*}{$\begin{array}{l}\text { SAR } \\
(\text { epm) }\end{array}$} \\
\hline & \begin{tabular}{|c|}
$\mu \mathrm{Mhos}$ \\
$/ \mathrm{sec}$
\end{tabular} & & d) & & & & & & & & & & & & \\
\hline 1 & 2880 & 7.8 & 786.33 & $\mathrm{~g} / \mathrm{l}$ & 53.31 & 69.19 & 63.20 & 96.52 & 30.96 & 60.01 & 1.52 & 264.17 & 764.18 & 30.55 & .856693 \\
\hline 2 & 3850 & 7.6 & .30 & $\mathrm{~g} / \mathbf{l}$ & 83.37 & 121.47 & 9.09 & 125.05 & 92 & 5.00 & 99.82 & 195.49 & 1170.92 & .39 & 322 \\
\hline 3 & 2440 & 7.4 & 9.47 & $\mathrm{~g} / \mathrm{l}$ & 56.71 & 4.99 & 3.98 & 76.20 & 48 & 5.00 & 33.04 & 253.12 & 37.94 & 6.76 & \\
\hline 4 & 1307 & 7.1 & 1212.78 & $\mathrm{~g} / \mathrm{l}$ & 79.96 & 35.63 & 80.13 & \begin{tabular}{|l|}
63.31 \\
\end{tabular} & 72 & 18.00 & 31.85 & 232.95 & 86.88 & .16 & 548009 \\
\hline 5 & 1686 & 7.3 & 47.14 & $g / l$ & 50.10 & 42.56 & 21.99 & 69.56 & 70 & 30.00 & 22.03 & 381.84 & 90.07 & .95 & 2904 \\
\hline 6 & 95 & 7.2 & 92 & $\mathrm{~g} / \mathbf{I}$ & 40.08 & 3.91 & 4.04 & & & 5.00 & .03 & & & & \\
\hline 7 & 1285 & 7.1 & 222.75 & $\mathrm{~g} / \mathrm{l}$ & 59.92 & 50.22 & 242.41 & 63.31 & 19.28 & 18.00 & 13.54 & 460.13 & 221.99 & .94 & 6189 \\
\hline 8 & 2290 & 7.4 & 447.06 & $\mathrm{~g} / \mathrm{l}$ & 53.31 & 47.79 & 44.99 & 76.20 & 23.54 & 30.00 & 152.53 & 360.71 & 457.80 & 3.92 & 3491 \\
\hline 9 & 75 & 7.3 & & $\mathrm{~g} / \mathrm{l}$ & 53.31 & 3.38 & & & & .01 & & & & & \\
\hline 10 & 1046 & 7 & 1059.02 & $\mathrm{~g} / \mathrm{l}$ & 100.00 & 46.57 & 100.28 & 125.44 & 1 & 30.00 & 122.03 & 460.61 & 35.11 & 6.40 & 7619 \\
\hline 11 & 1219 & 7 & 37.26 & $g / 1$ & 89.98 & \begin{tabular}{|l|l|}
58.37 \\
\end{tabular} & 151.56 & \begin{tabular}{|l|l|}
64.87 \\
\end{tabular} & 54 & 15.00 & 44.05 & 287.22 & 48.23 & 48 & 7684 \\
\hline 12 & 2520 & 7.5 & 6.91 & $\mathrm{~g} / \mathrm{l}$ & 73.35 & 33 & & & & .00 & .43 & & & & \\
\hline 13 & 1257 & 7.3 & 938.14 & $\mathrm{~g} / \mathrm{l}$ & 50.10 & 54.72 & 85.60 & 50.80 & $\mathbf{1 6 . 3 7}$ & 15.00 & 256.25 & 182.52 & 28 & 15 & 596 \\
\hline 14 & 1229 & 7.3 & 735.07 & $g / 1$ & 30.06 & 45.36 & 37.99 & 3.31 & 2.85 & 30.00 & 2.03 & 96.06 & 28 & 65 & 354 \\
\hline 15 & 1271 & 7.1 & 57 & $g / l$ & 50.10 & 2.65 & 62 & 5 & & 0.00 & .54 & 09 & & & 121 \\
\hline 16 & 1271 & 7.1 & 896.28 & $\mathrm{mg} / \mathrm{l}$ & 43.29 & 46.21 & 183.99 & 57.05 & 2 & 24.00 & 207.44 & $\mathbf{1 7 9 . 1 5}$ & 258.87 & 23 & 276 \\
\hline 17 & 01 & 7.3 & 894.61 & $g / l$ & 43.29 & 48.15 & 32.84 & 50.80 & .37 & 30.00 & 33.04 & 152.26 & 74 & .51 & 13 \\
\hline 18 & 27 & 7.2 & 6.02 & $g / 1$ & 59.92 & 3.15 & 4.10 & 63.3 & & 0.00 & .54 & 4.97 & 79 & 30 & 864 \\
\hline 19 & 1467 & 7.2 & 1014.44 & $\mathrm{mg} / \mathrm{l}$ & 33.27 & 46.57 & 229.99 & 69.56 & 17.27 & 18.00 & 262.36 & 177.71 & 308.16 & 17.29 & 5716 \\
\hline 20 & 17 & 7.1 & 862.64 & $\mathrm{mg} / \mathrm{l}$ & 33.27 & 52.65 & 77.09 & 57. & & 30.00 & 4.05 & 4.09 & 45 & 5 & 306 \\
\hline 21 & 1283 & 7 & 896.74 & $\mathrm{mg} / \mathrm{l}$ & 33.27 & 44.50 & 94.11 & 57.05 & & 15.00 & 4.56 & 169.07 & 45 & 47 & 896 \\
\hline 22 & 1183 & 7 & 794.43 & $\mathrm{mg} / \mathrm{l}$ & 36.67 & 41.71 & 162.60 & 50.80 & & 30.00 & 158.63 & 109.99 & & .88 & 9549 \\
\hline 23 & 1505 & 7.4 & \begin{tabular}{|l|l|}
941.45 \\
\end{tabular} & $\mathrm{mg} / \mathrm{l}$ & 56.71 & 61.16 & $\mathbf{1 7 4 . 1 0}$ & 57.05 & 16.89 & 15.00 & 256.25 & 128.72 & 320.57 & 16.42 & 1856 \\
\hline 24 & 1205 & 7.1 & \begin{tabular}{|l|}
844.21 \\
\end{tabular} & $\mathrm{mg} / \mathrm{l}$ & 40.08 & 38.91 & 162.60 & 76.20 & 22 & 15.00 & 219.65 & 155.14 & 246.45 & .28 & 4628 \\
\hline 25 & 1215 & 7.15 & 851.26 & $\mathrm{mg} / \mathrm{l}$ & 36.67 & 51.80 & 171.11 & 50.80 & 14.83 & 15.00 & 195.24 & 121.52 & 306.74 & 14.88 & 263628 \\
\hline 26 & 1255 & 7.1 & \begin{tabular}{|c|}
901.27 \\
\end{tabular} & $\mathrm{mg} / \mathrm{l}$ & $\mathbf{5 0 . 1 0}$ & 52.65 & 162.60 & 63.31 & 15.52 & $\mathbf{1 5 . 0 0}$ & 274.56 & $\mathbf{1 7 3 . 8 7}$ & 246.45 & 15.57 & 25816 \\
\hline 27 & 1831 & 7.4 & 1053.47 & $\mathrm{mg} / \mathrm{l}$ & 50.10 & 48.64 & 230.45 & 63.31 & 18.14 & 21.00 & 201.34 & 132.56 & 406.74 & 18.23 & 58096 \\
\hline 28 & 4730 & 7.9 & 2301.46 & $\mathrm{mg} / \mathrm{l}$ & 96.59 & 98.01 & $\mathbf{5 7 4 . 9 8}$ & 78.94 & 39.90 & 15.00 & 207.44 & 163.30 & 1170.92 & 40.32 & 5138 \\
\hline 29 & 3020 & 7.7 & 844.88 & $\mathrm{mg} / \mathrm{l}$ & 69.94 & 47.79 & 473.55 & 82.84 & 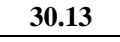 & 15.00 & 244.05 & 441.88 & 591.84 & 30.39 & 6898 \\
\hline 30 & 4680 & 7.8 & 2973.93 & $\mathrm{mg} / \mathrm{l}$ & 116.63 & 105.30 & $\mathbf{7 5 7 . 8 2}$ & 101.60 & $\mathbf{5 0 . 0 3}$ & 15.00 & 109.82 & 528.34 & 1294.33 & 49.80 & 24577 \\
\hline 31 & 1535 & 7.3 & 11138.42 & $\mathrm{mg} / \mathrm{l}$ & 66.73 & 54.72 & 233.21 & 39.08 & 18.97 & 15.00 & 213.54 & $\mathbf{3 3 9 . 5 8}$ & 283.33 & 19.06 & 5.124743 \\
\hline 32 & 1519 & 7.2 & 1108.73 & $\mathrm{~g} / \mathrm{l}$ & 66.73 & 57.76 & 224.01 & 30.48 & & 15.00 & 213.54 & 336.70 & 271.28 & 18.66 & 4.845831 \\
\hline 33 & 1756 & 7.4 & 4.72 & $\mathbf{g} / \mathbf{1}$ & 63.33 & 3.69 & 5.36 & 7.44 & 8 & 30.00 & 274.56 & 59.46 & 8.16 & 17.51 & 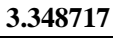 \\
\hline
\end{tabular}

Date of sampling: 8/2015 Date of analyses: 9/2015 
Table 6: Classification and description of conductivity and sodium

a- Conductivity classification (C) and description.

\begin{tabular}{|c|l|l|}
\hline C & \multicolumn{1}{|c|}{ degree } & \multicolumn{1}{c|}{ Description } \\
\hline C1 & Lo salinity water & Good \\
\hline C2 & Moderate to saline water & Good for soils of medium permeability for most plants. \\
\hline C3 & Medium to high saline water & $\begin{array}{l}\text { Satisfactory for plants having moderate salt tolerance, on soils of } \\
\text { moderate permeability with leaching. }\end{array}$ \\
\hline C4 & High saline water & $\begin{array}{l}\text { Satisfactory for salt tolerant crops on soils of good permeability with } \\
\text { special leaching }\end{array}$ \\
\hline C5 & Excessive saline water & Not fit for irrigation \\
\hline
\end{tabular}

b- Sodiumy classification (S) and description.

\begin{tabular}{|c|l|l|}
\hline S & \multicolumn{1}{|c|}{ degree } & \multicolumn{1}{c|}{ Description } \\
\hline S1 & Low sodium water & Good \\
\hline S2 & Medium sodium water & $\begin{array}{l}\text { Good for coarse grained permeability soils unsatisfactory for highly } \\
\text { clayey soils with low leaching. }\end{array}$ \\
\hline S3 & High sodium water & $\begin{array}{l}\text { Suitable only with good drainage, high leaching and organic matter } \\
\text { addition, some chemical additives. }\end{array}$ \\
\hline S4 & Very high sodium water & Unsatisfactory. \\
\hline
\end{tabular}

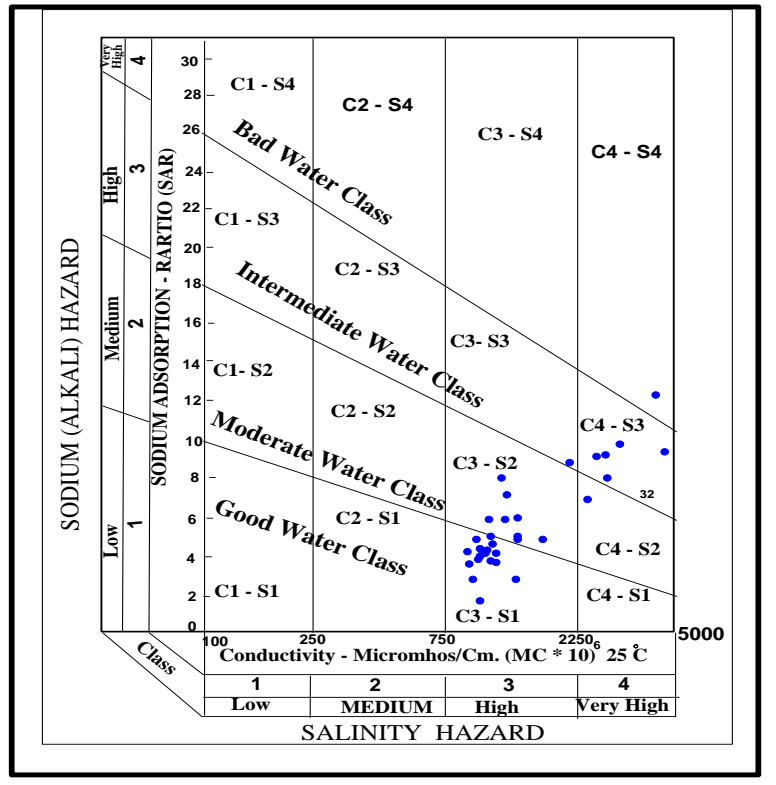

Fig. 19: Groundwater classification for irrigation according to ${ }^{[29]}$.

\section{Conclusion}

West Samalot area occupies a part of the desert fringes. The western desert road (Cairo-Assuit) runs upon the eastern parts of the area of study. It is covered by the Middle Eocene carbonate rocks (Samalot Formation). The low lands are covered by Oligocene - Pleistocene sand and gravels as well as some Oligocene Basaltic extrusions. The area of study is mainly affected by the structural setting of the Red Sea and the Gulf of Suez. The dominated faults reflect the NW-SE trend with throws range between $50 \mathrm{~m}$ and $35 \mathrm{~m}$ to the East. The NE-SW and E-W normal faults occur.

The Samalot fractured limestone represents the available water bearing rocks in west Samalot area. The maximum penetrated thickness in the area of study reaches $225 \mathrm{~m}$. It occurs under free water table condition. The geometry of the aquifer is controlled by the fracture density, caves and fissures, which store and transmit the groundwater. The depth to water ranges between $109.43 \mathrm{~m}$ to the west and $14.3 \mathrm{~m}$ to the east. The western subsurface water bearing buried channels may be responsible for the recharging flow to the east, towards the area of study. The groundwater flows to the east and northeast due Abo Edahab and Bahr Youssef canals, which act as drains. The study area will suffer from water depletion, where the annual drop in water level ranges between $0.5 \mathrm{~m}$ and $2.45 \mathrm{~m}$. The higher transmissivity values $\left(4394.9 \mathrm{~m}^{2} / \mathrm{d}\right.$ $3515.929 \mathrm{~m}^{2} / \mathrm{d}$ ) exist along the eastern highly dissected area. While the lowest values $\left(274.68 \mathrm{~m}^{2} / \mathrm{d}-15.13 \mathrm{~m}^{2} / \mathrm{d}\right)$ occur in the western parts. The salinity increases due east coinciding with the direction of flow. It ranges between $735.7 \mathrm{ppm}$ and $1844.88 \mathrm{ppm}$ except three samples, which affected by returned flow processes, have a maximum value $2973.93 \mathrm{ppm}$. Most of the water samples are of sodium chloride and some are of sodium sulphate water type. All water samples suitable for agricultural and livestock uses.

\section{Recommendations}

1- The reclamation activities must be directed to the most eastern and southern parts in the area of study because they have high groundwater potentiality and low depth to water (low drilling coast).

2- The flood irrigation system is not suitable because it causes the increase of aquifer salinity through the returned flow, consumption a lot of water, drop in groundwater level and future water depletion.

3- The percussion drilling is preferred than the hydraulic rotary for groundwater wells to avoid the filling of the fissures and cracks with drilling mud fluid and then the decreasing of the porosity and permeability.

4- The western parts of the investigated area need a future geophysical exploration studies to follow the subsurface water bearing buried channels.

5- It is preferred to let the drilled wells as open well bore (self-support) without screens to minimize the 
drawdown in groundwater level inside the well during the discharge (well losses $\mathrm{C}$ ).

6- The appreciation of the factors affecting well efficiency can thus lead to savings in construction and operating costs.

\section{References}

1) Said, R. (1981). The geological evaluation of the River Nile. Springer verlag New York, 151p.

2) Said, R. (1990). The geology of Egypt. A.A. Balkema/Rotterdam/Brookfield, 734p.

3) Ezzat, A. M. (1974). Regional hydrogeologic conditions. Minstry of agriculture and land reclamation, Cairo, Egypt.

4) Khalifa, M. A. (1981). Geological and sedimentological studies of west Beni Mazar area, south El-Fayum province, Western Desert, Egypt. Ph.D. Thesis.

5) Mansour, H. H. and Philobbos, E. R. (1983). Lithostratigraphic classification of the surface Eocene Carbonates of Nile Vally, Egypt. Areview. Bull. Fac. Sci, Assuit Univ., 12(2c).

6) Strougo, A. (1986). Mokattamian stratigraphy of eastern Maghagha-El Fashn district, Mid. East Res. Cent. Ain Shams Univ. Sci. Res. Ser.; 33-58.

7) El Sayed, E. A. (1987). Hydrogeological evaluation of the groundwater resources in El Minia district, Egypt. M.Sc. Thesis, Geol. Dept., El Minia Univ., $115 \mathrm{p}$.

8) Abdel Aziz, R. S. (1994). Geological and sedimentological studies In West El Minia - Beni Mazar area, Egypt. M.Sc. Thesis.

9) Abel Baky N. F. (2013). Exploring groundwater possibility in the area west of El Fayoum-Asuit road using remout sensing, geophysical and GIS techniques. Ph.D. Thesis.

10) Conoco (1987). Geologic map (scale 1:500.000), Beni Suef chart.

11) Joint Venture Qattara (1978). Study QattaraDepression. Special Volume: Regional geology and hydrogeology, unpublished report of Lahmeyer Int. $\mathrm{GmbH}$, Salzgitter Consult GmbH, Deutsche Project Union $\mathrm{GmbH}, 126 \mathrm{p}$.

12) EL Boukhary, M. A. and abdelmalik, W. (1983). Revision of the strataigraphy of the Eocene deposits in Egypt. N. Jb., Geol. palaont. Mh., Stuttgart, 6:321-337.

13) IWACO/RIGW (1986). Feasibility of vertical drainage in the Nile valley, Minia Pilot area. Ministry of irrigation, Cairo, Egypt.

14) Abou Heleika, M., and Niesner, E. (2009). Configuration of the limestone aquifers in the central part of Egypt using electrical measurements. Hydrogeology J., 17(2):433-446.
15) El Kashouty, M. (2010). Modeling of the limestone aquifer using isotopes, major, and trace elements in the western River Nile between Benisuef and El Minia. Fourteenth International Water Technology Conference, Cairo, Egypt; 941-968.

16) El-Sayed, M. H. (2007). Hydrogeochemistry of the Tertiary-Quaternary aquifers In the newly reclaimed areas in El-Minia governorate, Egypt. Bul. Ain Shams Univ., 45: 22.

17) Shabana, A. R. (2014). Geology of water resources of Wadi El Tarfa, Eastern Desert, Egypt. Egy. J. geology, 58:41-59.

18) Greene, E. A., Shapiro, A. M. and Carter, J. M. (1999). Hydrogeologic characterization of the Minnelusa and Madison aquifers near spearfish, South Dakota. US Geol. Surv., Water Resour. Inv. Rept. 98:4156-4164.

19) Kresic, N. (2007). Hydrogeology and groundwater modeling. CRC Press, second edition, 828p.

20) Cooper, H. H. and Jacob, C. E. (1946). A generalized graphical method for evaluation formation constants and summarizing well history. Am. Geophys. Union.Trans.; 27526-27534.

21) Gheorghe, A. (1979). Processing and synthesis of hydrogeological data. Abacus press, $390 \mathrm{p}$.

22) U.S. Department of the Interior (1981). Ground water manual. Chapter 2.

23) Kruseman, G. P. and De Ridder, N. A. (1990). Analysis and evaluation of pumping test data. International institute for land reclamation and improvement, the Nitherlands, 377p.

24) Walton, W. C. (1962). Selected analytical methods for well and aquifer evaluation. Illinois state water survey, Bull. 49: 81p.

25) Rorabaugh, M. I. (1953). Graphical and theoretical analysis of step-drawdown test of artesian well. Proceedings Am. Soc. Civil Engineers, v 79.

26) Bierschenk, W. H. (1961). Determining well efficiency by multiple step-drawdown tests. GroundWater Resources in Iran, International Association of Scientific Hydrology, Symposium of Athens, Publication 57(II): 607.

27) Hem, J. D. (1989). Study and Interpretation of the Chemical Characteristics of Natural Water. U.S. Geol. Survey Water Supply. paper 2254, $3^{\text {rd }}$ edition, p. 248 .

28) Tood, D. K. (1980). Groundwater hydrology. John Wiley and Sons, Inc., New York, U.S.A., 535p.

29) Makee, J. E. and wolf, H. W. (1963). Water quality criteria,California stat, Quality Board, Publ. 3A.

30) U. S. Salinity Laboratory Staff (1954). Diagnosis and improvement of saline and alkali soils. U.S. Dept. Agri., Handbook, Washington, D.C., 60:1-60. 